\title{
FENOMENA BLACK CAMPAIGN DALAM PEMILIHAN KEPALA DAERAH 2015
}

\author{
Ade Tuti Turistiati \\ adetuti30@yahoo.com.au \\ Dosen Institut STIAMI
}

\begin{abstract}
ABSTRAK. Jumlah artis yang terlibat dalam kegiatan politik di Indonesia semakin meningkat. Hubungan antara artis dengan politisi dapat saling melengkapi. Pada umumnya para artis cenderung berkontribusi untuk mendongkrak perolehan suara dalam suatu pemilihan termasuk pemilihan kepala daerah (Pilkada) 2015. Di dalam mobilisasi masa, bagaimanapun issue kampanye hitam tidak dapat dihindari. Tulisan ini merupakan studi deskriptif tentang kampanye hitam yang terjadi pada calon Wakil Wali Kota Palu Sigit Purnomo Said Syamsuddin, vokalis band Ungu yang dikenal dengan panggilan Pasha. Media massa memainkan peranan penting dalam menyebarkan kampanye hitam. Kenyataannya banyak pemilih yang berkepala batu. Mereka cukup selektif dalam mengantisipasi kampanye hitam.)
\end{abstract}

Kata kunci: black campaign, media massa, pemilihan, pemilih berkepala batu

ABSTRACT. Numbers of artists who are involved in political activities in Indonesia are increasing. The relationship between artists and politicians can be complementary. In general, the artists tend to contribute more to boost votes in the elections, including in local elections of district heads (Pilkada) 2015. However, in a mass mobilization, issues of black campaign are inevitable. This paper is a descriptive study about black campaign against the candidate for Vice Mayor of Palu, Sigit Purnomo Said Syamsuddin, Ungu band vocalist known as Pasha. Mass media play an important role in spreading black campaign. In fact, now many voters are an obstinate audience. They are quite selective in anticipating the black campaign.

Key words: black campaign, mass media, election, obstinate audience

\section{PENDAHULUAN}

\section{Latar Belakang}

Pilkada serentak 2015 baru saja berlalu. Pilkada tersebut tidak luput dari isuisu sekitar kampanye hitam yang menerpa para calon gubernur dan wakil gubernur serta bupati dan wakil bupati atau walikota dan wakil walikota. Kampanye hitam ini banyak terjadi karena pilkada hanya dilakukan satu putaran. Para kontestan melaui tim sukses-nya diduga melakukan segala metode kampanye untuk menang, termasuk kampanye hitam.

Aturan materi kampanye sebenaranya sudah cukup jelas seperti yang dinyatakan dalam Undang-Undang (UU) Nomor 8/2015 tentang Pilkada, pasal 69 Huruf (b) yaitu : "Dalam kampanye dilarang menghina seseorang, agama, suku, ras, golongan, calon gubernur, calon wakil gubernur, calo $\mathrm{n}$ bupati, calon wakil bupati, calon wali kota, calon wakil wali kota, dan/atau partai politik." Sementara itu, Pasal 69 Huruf (c) berbunyi, "Dalam kampanye dilarang melakukan kampanye berupa menghasut, memfitnah, mengadu domba partai politik, perseorangan, dan/atau kelompok masyarakat."

Cara pembuktian kampanye hitam tidak dapat dilakukan dengan mudah. Sebagai contoh, materi yang berisi fitnah dan penghinaan dilakukan dalam komunikasi antarpribadi atau mulut ke mulut. Undangundang dan peraturan Komisi Pemilihan Umum (PKPU) jelas melarang ini. Selain itu 
dugaan kampanye hitam pun kerap diberitakan media massa, seperti media cetak dan televisi.

Menurut Cangara (2014) setiap usaha untuk mengisi jabatan, terutama untuk jabatan publik, maka gossip yang mengarah pada bentuk kampanye hitam selalu muncul. Kampanye hitam yang biasa disebut black campaign cenderung menyudutkan para calon yang diusung untuk menduduki suatu jabatan. Isu itu biasanya erat kaitannya dengan apa yang disebut "3Ta", yaitu : Harta, Wanita, dan Tahta. Harta biasanya diisukan dalam bentuk korupsi, wanita dalam bentuk istri simpanan atau perselingkuhan, sedangkan tahta dinilai sikap ambisius.

Secara umum yang disebut dengan kampanye hitam adalah memfitnah, mengadu domba, menghasut, menghina, atau menyebarkan berita bohong yang dilakukan oleh seorang calon/sekelompok orang/partai politik/ pendukung seorang calon, terhadap lawan mereka. Jika bentuknya kritik terhadap visi dan misi atau program calon tertentu, hal tersebut tidak tergolong black campaign.

Salah satu fenomena kampanye hitam terjadi pada calon wakil Wali Kota Palu, Sigit Purnomo Syamsuddin Said, atau yang akrab dipanggil Pasha. Pasha selain sebagai vokalis band Ungu juga merupakan partisipan Partai Amanat Nasional (PAN).

Beredarnya foto-foto mesra yang diduga vokalis band Ungu tersebut dengan seorang wanita yang diduga sebagai artis Angel Karamoy banyak menyedot perhatian masyarakat. Namun, pihak keluarga Pasha dan sebagian masyarakat terutama pendukung dan penggemarnya meyakini bahwa foto-foto tersebut merupakan upaya black campaign karena vokalis band Ungu tersebut tengah maju sebagai wakil Wali Kota Palu mendampingi Hidayat sebagai calon Wali Kota Palu. Pasha diusung oleh Partai Amanat Nasional (PAN) sementara Hidayat didukung oleh Partai Kebangkitan Bangsa (PKB).

\section{Rumusan Masalah}

Penelitian ini akan menganalisis fenomena kampanye hitam dalam pilkada 2015 yang terjadi pada calon wakil Wali Kota
Palu, Sigit Purnomo Syamsuddin Said. Pertanyaan penelitian sebagai berikut:

1) Bagaimana peran media dalam penyebaran kampanye hitam yang menimpa Sigit Purnomo Syamsuddin Said atau Pasha?

2) Bagaimana dampak kampanye hitam terhadap pemenangan pasangan HidayatPasha?

\section{METODE}

Metoda penelitian yang digunakan adalah metoda deskriptif. Penelitian deskriptif adalah salah satu jenis metode penelitian yang berusaha menggambarkan dan menginterpretasi objek apa adanya.

Penelitian deskriptif ini juga sering disebut noneksperimen, karena pada penelitian ini peneliti tidak melakukan kontrol dan manipulasi variabel penelitian. Deskriptif diartikan sebagai prosedur pemecahan masalah dengan menggambarkan keadaan objek penelitian berdasarkan fakta yang tampak (Nawawi, 1983). Objek penelitian ini adalah teks-teks yang tersebar di media massa cetak dan on line, serta televisi nasional.

\section{TINJAUAN PUSTAKA}

Teori dan konsep yang digunakan dalam analisis penelitian ini adalah komunikasi politik, teori jarum hipodermik, teori khalayak kepala batu, dan kampanye hitam.

\section{Komunikasi Politik}

Menurut Mulyana (2013) komunikasi politik lazim didefinisikan sebagai suatu proses linear atau suatu sistem. Pendekatan linear ini berorientasi pada efek atau pengaruh pesan politik, sedangkan pendekatan sistem berorientasi pada kestabilan atau kesinambungan suatu sistem politik.

Nimmo (2011) menyebutkan cakupan komuniksai politik terdiri dari komunikator politik, pesan politik, persuasi politik, media komunikasi politik, khalayak politik dan akibat-akibat komunikasi politik. Dari segi aplikasinya, sudah lama komunikasi ditelaah untuk tujuan kampanye politik pemilu dan 


\section{TRANSPARANSI}

Jurnal Ilmiah Ilmu Administrasi

ISSN 2085-1162

masalah lain yang berkaitan dengan proses pengambilan keputusan politik.

Komunikasi politik di negara-negara sedang berkembang seperti Indonesia biasanya menggunakan dua sistem komunikasi dominan, yaitu media massa modern dan sistem komunikasi tradisional (Schramm, 1964 dalam Nimmo, 2011 ). Untuk memengaruhi masyarakat, maka sangat perlu untuk memilih sarana komunikasi yang tepat, sesuai dengan keperluan dan kepada siapa pesan politik ingin disampaikan.

Untuk masyarakat perkotaan kelas menengah, komunikasi politik melalui media massa sangat efektif karena pola hidup mereka yang sibuk tidak memberi mereka peluang untuk melakukan komunikasi langsung dengan orang lain. Apalagi kalau mereka tidak punya kepentingan langsung dengan sang komunikator. Bagi mereka, media massa cetak dan elektronik merupakan sarana paling efektif untuk mengetahui dan menyampaikan umpan balik setiap pesan politik yang ada.

Sementara untuk masyarakat pedesaan, apalagi masyarakat pedalaman yang secara literal tidak memiliki tradisi baca, pesan politik hanya bisa disampaikan oleh sistem komunikasi tradisional. Dalam konteks ini, seperti diungkap oleh Astrid Susanto (1978), komunikasi yang paling efektif adalah dengan menggunakan sistem komunikasi lokal yang sesuai dengan budaya mereka. Pendekatan-pendekatan interpersonal dengan tokoh-tokoh kampung menjadi pengatur lalu lintas opini menjadi kunci keberhasilan dalam sistem komunikasi tradisional ini.

http://referensiassyariabdullah.blogspot.co.id/ 2008/05/pemberdayaan-opini-publik.

Oleh sebab itu, tidak heran bila banyak pasangan kandidat dan tim sukses melakukan berbagai pendekatan dan strategi untuk memengaruhi opini sang tokoh, dengan harapan tokoh tersebut akan menggunakan pengaruhnya untuk memilih sang kandidat. Pola-pola ini merupakan pola-pola umum yang digunakan hampir oleh semua kandidat dalam bursa politik di Indonesia.
Penggunaan media massa untuk kepentingan kampanye bisa dikatakan masih sangat terbatas. Hanya beberapa kandidat yang mengiklankan dirinya di tabloid, internet dan koran lokal di Indonesia. Selebihnya mereka lebih memilih untuk mengkampanyekan dirinya melalui kalender, stiker, dan spanduk yang biayanya jauh lebih murah dan bertahan lama.

\section{Teori Jarum Hipodermik (Hypodermic Needle Theory)}

Teori dari Wilbur Schramm, Everett M. Rogers, dan Shoemaker yang dikutip dalam Arifin (2011) ini menyatakan bahwa komunikasi politik berlangsung dalam sebuah proses seperti "ban berjalan" secara mekanis dengan unsur-unsur yang jelas, yaitu: sumber (komunikator), pesan (komunike), saluran (media), penerima (khalayak) dan umpan balik (efek). Artinya sumber mengirim pesan ke penerima melalui saluran tertentu dan menimbulkan akibat atau efek. Berdasarkan "hukum peliput" dapat dibuat prediksi yang bersyarat, yaitu jika ada (pesan tertentu), maka akan ada efek tertentu (pada penerima). Itulah sebabnya dalam model mekanistis, studi komunikasi politik difokuskan pada efek. Berdasarkan paradigma mekanistis dan unsur-unsur yang terkandung dalam proses komunikasi tersebut, secara sederhana Lasswell merumuskan dalam sebuah formula, "siapa berkata apa, melalui saluran apa, kepada siapa dan bagaimana efeknya?" (who say what, in which cnannel, to whom with what effect?). Kemudian formula Lasswell tersebut oleh Nimmo (1992) dijadikan sebagai dasar menganalisis komunikasi politik.

Paradigma mekanistis tersebut menghasilkan dua asumsi dasar: Pertama, penerima (komunikan) atau khalayak pasif atau tidak berdaya ketika menerima pesan dari komuniktor. Artinya komunikator dengan mudah memengaruhi komunikan atau khalayak. Kedua, media massa sangat perkasa dan bahkan kekuatannya mendekati gaib. Artinya semua pesan yang disalurkan oleh media massa dengan mudah memengaruhi khalayak. Bahkan, oleh McLuhan (dalam 
Littlejohn \& Foss, 2014) menyebut bahwa media itu sendiri adalah pesan (the medium is the message). Khalayak yang tak berdaya itu sering disebut khalayak pasif.

Konsep khalayak tak berdaya atau khalayak pasif dan asumsi media perkasa dari paradigma mekanistis itu, dengan mudah dikenal melalui berbagai literatur yang memuat teori dasar dengan nama yang berbeda seperti hypodermik needle theory (teori jarum hipodermik) dan bullet theory of communication (teori peluru).

Berdasarkan teori tersebut, komunikator politik (politisi, profesional dan aktifis) selalu memandang bahwa pesan politik apapun yang disampaikan pada khalayak, apalagi melalui media massa, pasti menimbulkan efek yang positif berupa cara yang baik, penerimaan atau dukungan. Itulah sebabnya kegiatan komunikasi politik banyak dilakukan melaui pidato pada rapat umum atau media massa.

Ternyata asumsi tersebut tidak benar seluruhnya, karena efek sangat tergantung kepada situasi dan kondisi khalayak, disamping daya tarik isi, dan kredibilitas komunikator. Bahkan berbagai hasil penelitian membuktikan bahwa media massa memiliki pengaruh lebih dominan dalam tingkat kognitif (pengetahuan) saja, tetapi kurang mampu menembus pengaruh pada sikap dan prilaku.

Tiap-tiap individu ternyata sangat aktif dalam menyaring, menyeleksi, dan bahkan memiliki daya tangkal atau daya serap terhadap semua pengaruh yang berasal dari luar dirinya. Tiap-tiap individu itu tidak mengalami pengaruh secara pasif, melainkan secara aktif. Jiwa individu sendiri memiliki potensi dinamis dalam mewujudkan sikap dan kelakuannya. Dengan demikian asumsi bahwa khalayak pasif dan media perkasa, tidak terbukti secara empirik. Meskipun demikian, "teori jarum hipodermik" tidak runtuh sama sekali karena tetap dapat diaplikasikan atau digunakan untuk menciptakan efektifitas dalam komunikasi politik. Teori jarum hipodermik atau teori peluru dan teori transmisi selanjutnya oleh para pakar digambarkan pula dalam bentuk model, itulah sebabnya teori-teori tersebut dilukiskan sebagai model linier dalam komunikasi politik yang berkembang dalam masyarakat, terutama yang menganut sistem politik otoritarian. Model linear hanya berlangsung satu arah, yaitu dari sumber (komunikator) kepada penerima (khalayak) hal itu ditentukan dalam paradigma mekanistis.

\section{Teori Khalayak Kepala Batu (The Obstinate Audience Theory)}

Teori dari L. A Richard (1936), Raymond Bauer (1964), Schramm \& Robert (1977) yang dikutip dalam Arifin (2011) menyatakan bahwa asumsi khalayak pasif itu gugur. Dengan gugurnya asumsi khalayak tidak berdaya atau khalayak pasif dan media perkasa seperti teori jarum hipodermik, berkembanglah sebuah asumsi baru, bahwa khalayak justru aktif dan sangat berdaya dan sama sekali tidak pasif dalam proses komunikasi politik. Bahkan, khalayak memiliki daya tangkal dan daya serap terhadap semua rangsangan yang menyentuhnya. Dalam hal itu para pakar termasuk Wilbur Schramm dan Roberts (dalam Nimmo 2011) mengokersi teorinya dan mengakui adanya teori baru yang dikenal dengan nama teori khalayak kepala batu (the obstinate audience theori). Teori ini merupakan bentuk penjabaran dari perspektif atau paradigma psikologis dalam komunikasi yang telah dipaparkan di muka.

Teori khalayak kepala batu itu dikembangkan oleh pakar psikologi-Raymond Bauer pada tahun 1964. Bahkan, telah diperkenalkan oleh I.A Richards sejak 1936 dan telah diamalkan atau dipublikasikan oleh ahli retorika pada zaman Yunani dan Romawi 200 tahun yang lalu. Raymond Bauer mengkritik potret khalayak sebagai robot yang pasif. Khalayak hanya bersedia mengikuti pesan, bila pesan itu memberi keuntungan atau memenuhi kepentingan dan kebutuhan khalayak. Komunikasi tidak lagi bersifat linear tetapi merupakan transaksi. Media massa memang berpengaruh, tetapi pengaruh itu disaring, diseleksi, dan diterima atau ditolak oleh filter konseptual atau faktorfaktor personal yang memengaruhi reaksi mereka. 
TRANSPARANSI

Jurnal Ilmiah Ilmu Administrasi

ISSN 2085-1162

Dengan teori khalayak kepala batu itu, fokus penelitian bergeser dari komunikator kepada komunikan atau khalayak. Para pakar, terutama pakar psikologi maupun sosiologi mencurahkan perhatian kepada faktor individu. Mereka mengkaji faktor-faktor yang membuat individu ini mau menerima pesanpesan komunikasi. Salah satu di antaranya adalah lahinya teori "model guna dan kepuasan (uses and grafititations theory). Model ini dibangung dengan asumsi dasar bahwa manusia adalah makhluk yang sangat rasional dan sangat aktif, dinamis dan selektif terhadap semua pengaruh dari luar dirinya.

Pada dasarnya teori khalayak kepala batu dan teori use and gratifications serta teori lainnya dan model yang sejenis dapat dimasukkan ke dalam kelompok besar perspektif atau paradigma psikologis dari komunikasi politik. Meskipun individu menerima pesan karena kegunaan atau karena untuk memenuhi kepuasan dirinya berdasarkan perbedaan individu, kategori sosial atau hubungan sosial, namun yang terpenting dalam perspektif psikologis ini ialah semua pesan politik itu diolah secara internal pada diri individu. Dengan demikian komunikasi politik dalam perspektif ini berlangsung secara internal dalam diri individu, yang juga dikenal dengan nama komunikasi intrapersona (intrapribadi). Teori khalayak kepala batu ini sangat penting menjadi kerangka acuan dalam melaksanakan komunikasi politik di negara demokrasi. Teori ini mengasumsikan bahwa (1) setiap individu mempunyai kemampuan untuk menyeleksi, menyaring dalam menerima informasi; (2) khalayak justru sangat berdaya dan sama sekali tidak pasif dalam proses komunikasi politik. Khalayak memiliki daya tangkal dan daya serap terhadap semua terpaan pesan kepada mereka.

\section{Kampanye dan Black Campaign (Kampanye Hitam)}

Roger dan Storey (Antar Venus, 2004) memberi pengertian kampanye sebagai serangkaian tindakan komunikasi yang terencana dengan tujuan menciptakan efek tertentu pada sejumlah besar khalayak yang dilakuan secara berkelanjutan pada kurun waktu tertentu. Perlu diperhatikan bahwa pesan kampanye harus terbuka untuk didiskusikan dan dikritisi. Hal ini dimungkinkan karena gagasan dan tujuan kampanye pada dasarnya mengandung kebaikan untuk publik bahkan sebagian kampanye ditujukan sepenuhnya untuk kepentingan dan kesejahtraan umum (public interest).

Kampanye dalam Pemilu pada dasarnya dianggap sebagai suatu ajang berlangsungnya proses komunikasi politik tertentu, yang sangat tinggi intensitasnya. Ini dikarenakan terutama dalam proses kampanye pemilu, interaksi politik berlangsung dalam tempo yang meningkat. Setiap peserta kampanye berusaha meyakinkan para pemberi suara/konstituen, bahwa kelompok atau golongannya adalah calon-calon yang paling layak untuk memenangkan kedudukan.

Kampanye hitam merupakan trend universal di gelanggang politik dunia. Di negara-negara yang demokrasinya sudah matang sekalipun, kampanye terhadap keburukan-keburukan lawan sering dilakukan. Namun, dalam konteks Indonesia yang memiliki kultur Ketimuran yang kuat, membuka keburukan-keburukan lawan masih belum bisa diterima secara terbuka, kecuali dalam kasus-kasus yang merugikan publik secara luas, seperti kasus korupsi.

\section{HASIL DAN PEMBAHASAN}

Kampanye hitam bukanlah sebuah pilihan dalam berpolitik. Selain mengandung unsur jahat dan melanggar norma, baik masyarakat atau pun agama, kampanye hitam juga memberikan pendidikan politik yang buruk bagi masyarakat. Upaya Menghalalkan segala cara yang melandasi dipilihnya bentuk kampanye hitam menunjukkan masih buruknya moral dan keimanan seorang politisi yang melakukan hal tersebut. Dengan adanya kampanye hitam dapat memengaruhi 
pencitraan terhadap kandidat calon dari partai politik tertentu.

Bentuk kampanye hitam salah satunya menerpa calon wakil Wali Kota Palu, Sigit Purnomo Syamsuddin Said, atau yang akrab dipanggil Pasha. Menjelang penyelenggaraan pilkada langsung yang jatuh pada tanggal 9 Desember 2015, tiba-tiba issue dugaan perselingkuhan Pasha dan Angel Karamoy muncul ke permukaan. Hampir seluruh media cetak, on line, dan televisi menyiarkan dugaan kasus perselingkuhan tersebut. Mengacu pada pendapat Cangara (2014: 294) mengenai "3Ta", Pasha terkena gossip yang mengarah pada bentuk kampanye hitam denga issue wanita, wanita dalam bentuk istri perselingkuhan.

Gambaran pemberitaan di media cetak, on line, maupun televisi yang merupakan black campaign terhadap Pasha adalah sebagai berikut:

1. Menyebarkan kejelekan atau keburukan tentang kontestan pilkada (dalam hal ini Pasha) dengan cara memunculkan cerita buruk atau cerita yang bertentangan dengan norma budaya maupun agama di Indonesia.

2. Untuk membuktikan cerita tersebut, si penyebar cerita menyertakan bukti fotofoto Pasha dan yang diduga sebagai Angel Karamoy. Foto-foto tersebut bisa saja benar-benar terjadi, bisa juga benarbenar terjadi tapi tidak terkait langsung dengan permasalahan, namun si penyebar foto berharap asumsi masyarakat terbentuk atau bisa juga foto tersebut hasil rekayasa / manipulasi dengan bantuan teknologi komputer.

3. Untuk lebih menguatkan cerita dan bukti foto-foto tersebut, dimunculkan saksi hidup yang bercerita perihal keburukan Pasha dan menghubungkan dengan cerita-cerita yang mirip yang pernah dilakukan sebelumnya.

Agar situasi semakin "ramai" dan menguatkan opini publik, maka pemberitaan, media cetak, on line, dan TV menampilkan hasil wawanca dengan suami Angel dan keluarga Pasha. Reaksi dari keluarga Angel (suami) lebih mengafirmasi dugaan perselingkuhan tersebut sementara dari pihak keluarga Pasha sebaliknya. Keluarga Pasha menyangkal dugaan perselingkuhan tersebut. Pihak keluarga dan teman-teman dekat Pasha menilai pemberitaan tersebut sebagai upaya kampanye hitam karena Pasha sedang bertarung dalam pemilihan wakil Wali Kota Palu bersama pasangannya, Hidayat.

Tayangan TV dan pemberitaan media cetak tentang issue Pasha-Angel lebih merupakan tambahan hiburan di panggung politik di tengah kasus persidangan MKD. Jika kita mengacu pada teori jarum suntik yang menyatakan bahwa khalayak itu menerima pemberitaan apa adanya alias pasif, mungkin ada benarnya jika yang dimaksud adalah khalayak yang kurang berpendidikan, tidak kritis, dan mudah dipengaruhi. Namun, dewasa ini banyak khalayak yang memahami dunia politik melalui media massa maupun media sosial sehingga mereka cukup kritis terhadap "permainan" politik di Indonesia. Dengan kata lain mereka menyikapinya dengan berkepala batu atau selektif. Teori khalayak kepala batu menempatkan khalayak sebagai khalayak aktif. Khalayak hanya bersedia mengikuti pesan, bila pesan itu memberi keuntungan atau memenuhi kepentingan dan kebutuhan khalayak. Komunikasi tidak lagi bersifat linear tetapi merupakan transaksi. Media massa memang berpengaruh, tetapi pengaruh itu disaring, diseleksi, dan diterima atau ditolak oleh filter konseptual atau faktor-faktor personal yang memengaruhi reaksi mereka. Khalayak memiliki daya tangkal dan daya serap terhadap semua terpaan pesan kepada mereka.

\section{Fungsi Media Massa}

Menurut Mc.Quail (dalam Littlejohn, 2014), secara umum media massa memiliki berbagai fungsi bagi khalayaknya yaitu pertama, sebagai pemberi informasi; kedua, pemberian komentar atau interpretasi yang membantu pemahaman makna informasi; ketiga, pembentukan kesepakatan; keempat, korelasi bagian-bagian masyarakat dalam pemberian respon terhadap lingkungan; kelima, transmisi warisan budaya; dan keenam, ekspresi nilai-nilai dan simbol budaya yang diperlukan untuk melestarikan identitas dan kesinambungan masyarakat. 
TRANSPARANSI

Jurnal Ilmiah Ilmu Administrasi

ISSN 2085-1162

Oleh karena itu media massa seharusnya menjadi sarana pencerahan dan transformasi nilai-nilai kebenaran agar masyarakat dapat melihat secara apa adanya. Media sebaiknya tidak memunculkan kesan yang terlalu menilai atau keberpihakan dalam masa kampanye pilkada. Seharusnya media menyampaikan informasi yang sebenarnya, jelas hitam putihnya. Sehingga masyarakat tidak terjebak pada pilihan mereka, karena persoalan pilkada adalah persoalan masa depan bangsa. Media harus mampu objektif dalam penayangan berita.

Banyak sedikitnya penayangan yang berhubungan dengan transformasi ataupun sosialisasi visi dan misi dari sebuah Partai maupun calon yang dijagokannya akan sangat memengaruhi penilaian masyarakat terhadapnya. Oleh karena itu, bagi yang ingin mendapat kemenangan suara harus mampu "menguasai" media ini dengan penayangan iklannya. Dengan tidak sedikit biaya tentunya.

Selain televisi, surat kabar atau media cetak memiliki andil dalam pembentukan persepsi masyarakat. Persepsi sangat dipengaruhi oleh informasi yang ditangkap secara keseluruhan. Begitu juga dengan pencitraan pada dasarnya juga dipengaruhi oleh informasi yang diterima dan dipersepsi. Informasi atau berita dalam media massa merupakan hasil seleksi yang dilakukan oleh gatekeeper yang dijabat oleh pemimpin redaksi atau redaktur pelaksana surat kabar. Berita merupakan salah satu informasi yang diberikan oleh surat kabar. Dalam hal penyajian berita harus melalui seleksi. Oleh karena adanya seleksi dalam pemuatan berita, maka tidak semua berita atau informasi yang ada dapat ter-expose. Berita yang dimuat biasanya hanya berita yang memiliki nilai jual. Ternyata media massa baik surat kabar maupun televisi berpengaruh sangat besar bagi pemenangan dalam pilkada. Komunikasi politik lebih efektif melalui sarana tidak langsung atau menggunakan media tersebut. Karena pesan yang disampaikan akan serentak diketahui oleh orang banyak di segala penjuru dan juga dapat diulang-ulang penayangannya. Persepsi, interpretasi, maupun opini publik mudah dipengaruhi lewat iklan maupun berita dalam media. Maka untuk menghindari terjadinya disfungsi media, media harus bisa menjadi penengah atau perantara antara pemerintah, elit partai, dan masyarakat. Di masa reformasi ini, dimana sudah mulai ada kebebasan pers seharusnya pers mampu mengubah pola kerjanya yang semula 'menjilat' pemerintah karena terpaksa, tetapi sekarang harus diusahakan untuk netral karena dijadikan sebagai alat kritik sosial bagi pemerintah maupun masyarakat.

\section{Dampak Kampanye Hitam}

Kampanye hitam pada umumnya berdampak negatif pada kontestan pemilu atau pilkada. Namun demikian, fakta membuktikan bahwa kadang-kadang kampanye hitam justru dapat menuai simpati, merupakan hiburan bagi masyarakat, dan mendongkrak populariatas sang kontestan.

Dalam kasus Pasha, menurut penulis, khalayak yang tidak mempunyai kepentingan apa-apa terhadap Pasha di panggung politik (khalayak di luar Palu) menyikapi kasus Pasha-Angel hanya sebagai gossip belaka. Gossip yang ditayangkan dalam program infotainment lebih bersifat hiburan. Alih-alih sebagai kampanye hitam, kemunculan Pasha di berbagai media justru dapat turut mendongkrak popularitasnya sekaligus mendongkrak pasangannya calon Wali Kota Palu, Hidayat. Sosok Drs. Hidayat, M.Si, atau yang dikenal dengan Hidayat mempunyai karier politik di pemerintahan sejak tahun 1989, dan karir terakhirnya sebelum mencalonkan diri sebagai Wali Kota Palu adalah Kepala Badan Penelitian dan Pengembangan Daerah Provinsi Sulawesi Tengah. Selain itu Hidayat mengetuai berbagai yayasan dan organisasi dengan latar belakang keluarga yang harmonis.

Sebelumnya kampanye hitam sudah banyak menerpa para calon-calon kepala daerah, sebut saja Risma, calon Wali Kota Surabaya yang diterpa isu korupsi dan Zumi Zola, calon Wali Kota Jambi yang terkena issu wanita simpanan. Berita tentang mereka 
tergantikan atau terlupakan dengan kasus yang lebih menasional bahkan mendunia yaitu sidang MKD.

Kampanye hitam terhadap dugaan perselingkuhan Pasha-Angel bisa jadi justru menuai simpati dari khalayak. Di luar kegagalannya membangun rumah tangga sebelumnya, sosok Pasha tampil sebagai pria yang sebenarnya tipe "rumahan", sayang keluarga, religious, dan bersuara bagus.

Berdasarkan hasil perhitungan cepat sementara pada tanggal 16 Desember 2015, pasangan calon Wali Kota Hidayat-Pasha mengungguli lawan-lawannya. Jika HidayatPasha benar-benar menang dalam pilkada, maka dugaan kampanye hitam terbukti atau tidak, tidak memengaruhi jalan Pasha menjadi wakil Wali Kota Palu selama khalayaknya kepala batu.

\section{SIMPULAN}

Media berperan besar memengaruhi khalayak melalui tayangan-tayangannya tentang fenomena kampanye hitam dalam pilkada Palu. Namun demikian, khalayak semakin pintar untuk memilah-milah dan menyeleksi berita (khalayak kepala batu).

Kampanye hitam pada umumnya berdampak negatif pada kontestan pemilu atau pilkada. Namun demikian, fakta membuktikan bahwa kadang-kadang kampanye hitam justru dapat menuai simpati, merupakan hiburan bagi masyarakat, dan mendongkrak populariatas sang kontestan. Singkat kata dalam kasus kampanye hitam berupa "ta" (wanita) terhadap dugaan perselingkuhan Pasha-Angel ternyata tidak begitu memengaruhi potensi kemenangan pasangan Hidayat-Pasha sebagai Wali Kota dan Wakil Walikota Palu. Buktinya berdasarkan perhitungan cepat pasangan Hidayat-Pasha unggul di pilkada kota Palu 2015.

\section{DAFTAR PUSTAKA}

Arifin, Anwar. 2011. Komunikasi Politik, Filsafat-Pradigma-Teori-Tujuan-Strategi dan Komunikasi Politik Indonesia, Yogyakarta: Graha Ilmu.
Cangara, Hafied. 2014. Komunikasi Politik, Konsep, Teori, dan Strategi, Jakarta: Raja Grafindo Persada.

Littlejohn, Stephen. 2014. Teori Komunikasi (Terjemahan dari Theories of Human Communication), Jakarta: Salemba Humanika.

Mulyana, Deddy. 2013. Komunikasi Politik Politik Komunikasi, Membedah Visi dan Gaya Komunikasi Praktisi Politik, Bandung: Rosdakarya.

Nawawi, Hadari. 1983. Metode Penelitian Bidang Sosial. Yogyakarta: Gadjah MadaUniversity Press.

Nimmo, Dan. 2011. Komunikasi Politik, Komunikator, Pesan, dan Media, Bandung: Rosdakarya.

Sanit, Arbit. 1990, Sistim

Politik Indonesia. Jakarta : Raja Wali Pers.

Venus, Antar. 2004. Manajemen Kampanye, Bandung : Simbiosa Rekatana Media

Websites: http://referensiassyariabdullah.blogspot.co.id/ 2008/05/pemberdayaan-opini-publik-dan.html 